\title{
The Role of Teachers in Planning Early Childhood Learning
}

\author{
Agus Sumitra $^{1, *}$, Rita Nurunnisa ${ }^{2}$, Ririn Hunafa Lestari ${ }^{3}$ \\ ${ }^{1,2,3}$ Institut Keguruan dan Ilmu Pendidikan (IKIP) Siliwangi, Cimahi. Indonesia \\ *Corresponding author. Email: delaguspiero@gmail.com
}

\begin{abstract}
The teacher as a planner and implementer of learning is the teacher's role that must be implemented. One of the roles is the administrator role. The administrator is one of the teacher's roles in planning a series of learning for a certain period following the rules of manufacture and arrangement. However, teachers feel inconvenience in compiling timeconsuming learning plans, so that the teacher's focus in teaching and learning activities is not effective. Therefore, the purpose of this study is to determine the role of teachers in planning early childhood learning. The research method used is descriptive quantitative with the analysis of the frequency distribution presentation obtained from a questionnaire given to the teacher as a data collection technique. The results showed that $62.5 \%$ of the teachers strongly agreed, $31.25 \%$ answered that the teachers agreed and $6.25 \%$ answered hesitantly. Therefore, it can be concluded that the teacher strongly agrees that the role of the teacher as administrator is more widely used so that it has an impact on the role of the teacher as the implementation of the learning process as a result of the analysis of the role of the teacher as a whole in the process of the educational series.
\end{abstract}

Keywords: The role of teachers, planning, early childhood.

\section{INTRODUCTION}

Educators or teachers have an important role in stimulating the growth and development of children, especially in early childhood of educational institutions, namely preschool [1]. By implementing a series of learning, the teacher will organize a series of learning starting from the creation and preparation of learning, implementing and evaluating a series of learning actions that have been implemented in a preschool institution to achieve the learning objectives that have been compiled [2]. The success or failure of the implementation of teaching and learning activities in preschool is dependent on the ability of teachers to carry out the functions and roles of teachers professionally based on learning objectives [3].

In addition, based on the Act of the Republic of Indonesia, number 20, year 2003 [4], it states that educators are individuals who are required to work professionally suitable to their duties; making planning concepts and carrying out the learning program directly with students, assessing learning outcomes, conducting coaching and training. Therefore, what the teacher must do is a reflection of the teacher's role in learning, especially learning for early childhood.
The role of the teacher in the learning sequence to be carried out consists of the role of the teacher as a learning planner and as the implementation of learning [5]. The role of the teacher as a learning planner includes the design of play activities in the form of annual programs, semester planning, weekly planning and daily planning [6]. From this statement, it can be concluded that the teacher's role in the learning planner is the teacher as an administrator. The role of the teacher during the process of teaching and learning activities is carried out includes facilitators, motivators, behaviour models, observers, peacemakers and caregivers [7].

What teachers need to compile for a learning plan is that teachers need to compile in three dimensions, namely the design of play activities in the form of semester, weekly and daily programs [8], [9]. The design of play activities in the form of a semester program makes sense of the contents of the list of themes and sub-themes for one semester, basic competencies as goals that must be achieved and time allocation for themes. The form of play activity plans in the form of a weekly program is made by including plans for learning activities that are prepared for one week through the development of various learning activities based on aspects of child development which are made in the form of theme projects, while the play activity plans in the form of a 
daily program explain activities in one day which include program identity, opening activities, core activities and closing activities as well as assessments tailored to indicators from the aspects of child development based on the child's age stage [8].

The focus of this research lies in the role of the teacher in planning lessons or administrators, which is currently being an issue of various circles. This is because the teacher's role as a guide is to guide students in facing various difficulties in the development and changes that occur in children through creative activities in various fields [3], [10]. This has a major role in children's learning. Although in practice, the role of early childhood teachers is the administrator in charge of carrying out educational administration in educational units. Therefore, administrators can be defined as individuals who are able to lead the implementation of activities based on a series of activities that have been created and compiled to organize [11]. However, based on the results of observations and interviews with several teachers, it was found that the teacher felt inconvenienced by making learning designs because the teacher did not focus on providing stimulation to the process of learning activities taking place. This is in accordance with the statement from the Minister of Education and Culture (Mendikbud) Nadiem Makarim [12] that the teachers lesson plans are very time-consuming, because teachers can make these files within 20 pages, so that teachers become lazy, besides that there is also the finding that teachers do not stop working.

Through the background of the problems described, this study was conducted to determine the role of teachers in planning learning in early childhood education based on the formulation of the problem in this study, namely how to analyse the role of teachers in early childhood learning planning?

\section{RESEARCH METHOD}

In this study, the researcher used a descriptive method with a quantitative approach that aims to explain and determine a phenomenon, an object event obtained from the data collected in the form of numbers that have meaning [4], [13]. This study uses an instrument in the form of a questionnaire given to teachers in Bandung city as the place and research subject. After the data was obtained, the data were analysed using a simple statistical analysis, namely analysis of the frequency distribution presentation which generated results in the form of a percentage with the aim of explaining the respondent's description of the teacher's role in planning the learning of early childhood in the form of a percentage.

\section{RESULT AND DISCUSSION}

The dimension of learning planning in the Early Childhood Education dimension consists of the design of play activities in the form of semester, weekly and daily programs [8]. This is the focus of the research by providing questionnaires to Early Childhood Education teachers to obtain data related to the role of teachers and learning planning in Early Childhood Education.

The results of the research data analysis using the percentage analysis of the frequency distribution. To find out the results of the data in the form of a percentage, there are steps that need to be done, namely (1) determining the ideal maximum score and ideal minimum score, (2) determining the ideal score range and the score interval, (3) obtaining the criteria value for the teacher's role in learning planning early childhood. The research results obtained are as follows:

1) The maximum ideal score is obtained from the number of statements multiplied by the highest score to obtain an equal of 275 .

2) The ideal minimum score is obtained from the number of statements multiplied by the lowest score so that the equal is 55 .

3) The ideal score range is obtained from the ideal maximum score minus the ideal minimum score so that 220 is obtained.

4) The score interval is obtained from the score range divided by 4 equal 55 .

From the results of these calculations above, the criteria for analysing the role of the teacher as administrator in planning children's learning are as follows:

Table 1. Criteria for teacher role analysis of Early childhood learning planning.

\begin{tabular}{|c|l|c|l|}
\hline No & \multicolumn{1}{|c|}{ Category } & $\begin{array}{c}\text { Score } \\
\text { Range }\end{array}$ & \multicolumn{1}{c|}{ Interpretation } \\
\hline 1 & Strongly agree & $220-275$ & Teachers strongly agree about their role as an administrator in lesson planning. \\
\hline 2 & Agree & $165-219$ & Teachers agree about their role as an administrator in lesson planning. \\
\hline 3 & Hesitate & $110-164$ & Teachers hesitate about their role as an administrator in lesson planning. \\
\hline 4 & Disagree & $56-109$ & Teachers disagree about their role as an administrator in lesson planning. \\
\hline 5 & Strongly Disagree & $1-55$ & Teachers strongly disagree about their role as an administrator in lesson planning. \\
\hline
\end{tabular}


After the criteria value is obtained, the percentage analysis of the frequency distribution for each criterion is as follows; of the 16 teacher respondents who filled out the questionnaire, 10 teachers answered strongly agree, 5 teachers answered agree and 1 teacher answered hesitate about the role of the teacher as administrator which is more widely used. If $62,5 \%$ of the teachers strongly agreed, $31,25 \%$ answered that the teacher agreed and 6, $25 \%$ answered hesitantly.

Based on those data above, it can be concluded that teachers agree that at the early childhood learning planning stage, the teacher acts as an administrator. This is consistent with the statement from This is the role of Early Childhood Education teachers in early childhood education [5] that when the teacher starts planning learning, the teacher will act as an administrator.

However, based on the results of interviews with several teachers, teachers were inconvenienced with the large number of files that must be made and completed, so that teachers tend to consider planning the learning rather than the implementation of learning. This is in accordance with the statement of Uus Koharudin, the Dean of FKIP UNPAS who stated that efforts to improve the quality of learning were not done by the teacher because the teacher thought too much about the preparation of learning planning so that they were busy doing their administrative duties [14]. In addition, this has an impact on the ability of teachers to create a pleasant classroom atmosphere because teachers are not creative and make innovations in their learning [15].

According to Suviati and Afifah [16] the planning of learning does not need to be done completely, but it is used as an outline to achieve learning objectives considering that students in early childhood learning activities are not arranged according to plan so that teachers need to innovate and improvise to lead children towards learning planning that has been made and arranged without coercion to the children.

Basically, the role of the teacher that needs to be developed is not only focused on administrators, but teachers need to be facilitators, motivators, behaviour models, observers, peacemakers, caregivers, liaisons in communication, trainers, storytellers, researchers and become people who pay attention to children's time in activities during learning and potential developers of students [1], [7], [17].

The results of this study are descriptive results to describe the role of teachers as administrators and to analyse the roles of Early Childhood teachers. Therefore, the results of this study can be used as initial data for further researchers in providing efforts to teachers in making it easier for teachers to arrange and make lesson plans so that other teacher roles can be implemented.

\section{CONCLUSION}

The teacher as planning and implementing a series of learning activities is the teacher's role that must be undertaken in the process of the learning series. The teacher's role in learning planning requires teachers to formulate and organize learning sequences to be carried out in the classroom within a semester, a week and a day in accordance with the rules set by the government in the field of early childhood education which are adjusted to school characteristics so that the role teachers become administrators. After the data is collected and analysed, the role of the teacher as administrator is quite inconvenience for the teacher in carrying out other roles, especially in the teaching and learning process because the making and programming of activities takes up the time and energy of educators so that in the learning process teachers become less creative, less innovative in making updates and lazy. What teachers and academics can develop regarding this problem after obtaining this data is for the intervention of PAUD teachers in making it easier for teachers to carry out the teacher's role as an administrator.

\section{REFERENCES}

[1] Rahma A. Peran guru anak usia dini di RA Bintang Kecil Wirobrajan Yogyakarta dalam perspektif pendidikan Islam [Bachelor Thesis, Universitas Islam Negeri Sunan Kalijaga Yogyakarta]. Yogyakarta; 2017. Available from: http:// digilib.uin-suka.ac.id/28812/1/13430016_ BA BI_IV-atau-V_DAFTAR-PUSTAKA.pdf.

[2] Safitri A, Hadiyanto, Ramli E. Persepsi guru tentang proses supervisi akademik kepala SMAN 1 Kecamatan Kapur IX Kabupaten Lima Puluh Kota. Jurnal Bahana Manajemen Pendidikan. 2018;7(1):11-18.

[3] Zakiya N. Pengembangan keprofesian berkelanjutan dalam meningkatkan profesionalisme guru pendidikan anak usia dini. Jurnal Obsesi: Jurnal Pendidikan Anak Usia Dini. 2019;3(2):356-365.

[4] Ministry of Education and Culture of Republic Indonesia. Sistem pendidikan nasional. UU No. 20 Tahun 2003 [Internet]. 2003. Available from: https://pusdiklat.perpusnas.go.id/public/media/regul asi/2019/11/12/2019_11_12-03_49_06_9ab7elfa5 24ba603bc2cdbeb7bff93c3.pdf.

[5] PAUD Jateng. Inilah peran guru PAUD dalam Pendidikan Anak Usia Dini [Internet]. Semarang: PAUD Jateng; 2015. [cited November 6, 2020]. Available from: https://www.paud.id/2015/11/peran -guru-paud-dalam-pendidikan-anak.html.

[6] PAUD Jateng. Peranan guru PAUD dalam perencanaan pembelajaran anak [Internet]. Semarang: PAUD Jateng; 2015 [cited November 06, 2020]. Available from https://www.paud.id/2015/ 
11/peranan-guru-paud-dalam-perencanaan-

pembelajaran.html.

[7] PAUD Jateng. Enam peran guru PAUD dalam proses pembelajaran [Internet]. Semarang: PAUD Jateng; 2015 [cited November 06, 2020]. Available from: https://www.paud.id/2015/11/peran-guru-pau d-dalam-pembelajaran.html

[8] Nuridiana, Sunarsih C. Modul guru pembelajaran Taman Kanak-kanak kelompok kompetensi C. Pusat Pengembangan dan Pemberdayaan Pendidikan dan Tenaga Kependidikan Taman Kanak-kanak dan Pendidikan Luar Biasa, Direktorat Guru dan Tenaga Kependidikan; 2016.

[9] Wahyuni M, Yuliantina I, Ritayanti, U. Penyusunan pelaksanaan pembelajaran pendidikan anak usia dini. Jakarta: Kementerian Pendidikan dan Kebudayaan. Direktorat Jenderal Pendidikan Anak Usia Dini dan Pendidikan Masyarakat Direktorat Pembinaan Pendidikan Anak Usia Dini; 2015.

[10] Willis S. Peran guru sebagai pembimbing (suatu studi kualitatif) [Internet]. File UPI. 2003. Available from: http://file.upi.edu/Direktori/JURNAL/JURN AL_MIMBAR_PENDIDIKAN/MIMBAR_NO_1_ 2003/Peran_Guru_Sebagai_Pembimbing_\%28Suat u_Studi_Kualitatif\%29.pdf.

[11] Kamus Besar Bahasa Indonesia (KBBI). [Internet]; 2016. Available from: https://kbbi.kemdikbud.go.id/ entri/administraSI (19 Maret 2020).

[12] Wicaksono A. Nadiem Usul RPP Selembar: Kasih Waktu Guru Istirahat [Internet]. Jakarta: CNN Indonesia. 2020 [Cited March, 11 2020]. Available from: https://www.cnnindonesia.com/nasional/201 91212195332-20-456505/nadiem-usul-rpp-selemba r-kasih-waktu-guru-istirahat.

[13] Sugiyono MP. Metode penelitian kuantitatif dan R\&D. Bandung: Alfabeta; 2008.

[14] Yanuar Y. Kualitas guru sulit naik jika terbebani administrasi [Internet]. Jakarta: Tempo; 2019 [cited December 13, 2019]. Available from https://tekno. tempo.co/read/1283244/nadiem-kualitas-guru-sulitnaik-jika-terbebani-administrasi/full\&view=ok.

[15] Sarnapi. Administrasi bikin guru tak kreatif, FKIP Unpas dukung Nadiem Makarim sederhanakan RPP jadi satu lembar [Internet]. Bandung: Pikiran Rakyat; 2020. [cited in January 2, 2020]. Available from, from: https://www.pikiran-rakyat.com/pendi dikan/pr01329474/administrasi-bikin-guru-tak-kre atif-fkip-unpas-dukung-nadiem-makarim-sederhan akan-rpp-jadi-satu-lembar?page $=2$.

[16] Sufiati V, Afifah. Peran perencanaan pembelajaran untuk performansi mengajar guru Pendidikan Anak Usia Dini. Jurnal Pendidikan Anak. 2019;8(1):4853.
[17] Miels J. The Seven Faces of the Early Childhood Educator [Internet]. Kenya: Early Childhood News.com; 2008. Available from: http://www. earlychildhoodnews.com/earlychildhood/article_vie w.aspx?ArticleID=171. 